\title{
The Effect of Foreign Portfolio Equity Sales on Stock Returns in Kenya: Evidence from NSE Listed Financial Institutions
}

\author{
Loice Koskei $^{1}$ \\ ${ }^{1}$ School of Business \& Economics, Africa International University, Nairobi, Kenya \\ Correspondence: Loice Koskei, P.O. Box 1670-30100, Eldoret, Kenya. Tel: 254-721-799-266. E-mail: \\ loikosy@yahoo.com
}

Received: March 3, 2017

Accepted: March 20, 2017

Online Published: March 25, 2017

doi:10.5539/ijef.v9n4p185

URL: https://doi.org/10.5539/ijef.v9n4p185

\begin{abstract}
Fluctuations of foreign portfolio equity intensify risk and unpredictability in financial institutions leading to high volatility. The main aim of this study was to find out the effect of foreign portfolio equity outflows on stock returns of listed financial institutions in Kenya. The study population was 21 financial institutions listed on the Nairobi Securities Exchange. Using purposive sampling technique the study concentrated on 14 financial institutions. The research design of the study was causal as it is concerned more with understanding the connection between cause and effect relationships. The study adopted panel data regression using the Ordinary Least Squares (OLS) method where the data included time series and cross-sectional. A unit root test was carried in this study to examine stationarity of variables because it used panel data which combined both cross-sectional and time series information. Panel estimation results indicated that foreign portfolio equity outflows have no effect on stock returns of listed financial institutions in Kenya. The study recommended implementation of policies that would curb foreign portfolio outflows in financial institutions in order to minimize reversals of foreign portfolio investments.
\end{abstract}

Keywords: foreign portfolio equity sales, stock returns, financial institutions, Nairobi securities exchange, Kenya

\section{Introduction}

Foreign portfolio flows are important to nations that are recipients of these flows as they have an opportunity to benefit from less expensive modes of financing. Nevertheless, they intensify a country's susceptibility to global economic meltdown which occurs during spontaneous reversals in foreign portfolio flows. The economic crisis of the 1980s, Latin America and the Association of Southeast Asian Nations in the 1990s and Argentina in 2001-02, are examples of the adverse effects resulting from uncertainties in foreign portfolio flows (Chen \& Quang, 2012). Although the economic turmoil in the United States of America (U.S.A.) and some parts of the group of European nations may have been agitated by many issues such as bank failures, property bubbles and government fiscal deficit, the crises were transmitted to other nations through financial intermediaries. The meltdown in these advanced economies that were believed to be resilient exposed the vulnerability of developing countries that depended on foreign inflows and the global financial system as a whole.

The surge in foreign portfolio flows to developing markets in 2009 and 2010 renewed the debate on the implications of these flows in receiving countries on the optimal policy responses (IMF, 2011). Foreign portfolio flows have consequences. In less financially integrated nations, increasing portfolio flows raise the probability of systemic sudden stops, i.e. large unexpected falls in capital inflows that could be accompanied by current account reversals. This could lead to a rapid increase in foreign currency-denominated debt, liquidity crises and credit rationing in the host country. However, increasing financial development and integration beyond a certain threshold level seems to decrease the likelihood of sudden stops and capital flow reversals, thus contributing to financial stability and market liquidity (Calvo, Izquierdo, \& Mejia, 2008).

According to Financial market theory, more profits ought to recompense for the greater risks in developing economies in the long run. For foreign investors, return depends on the value of the security during the start and end of a given time and on exchange rate, thus returns is approximately equal to the sum of domestic return on security and return on foreign currency (Sharpe, Gordon, \& Jeffery, 2003). This means that the rate of return of a country's currency has an impact on the pricing of equities in the domestic market. 


\subsection{Price Pressure Hypothesis}

The price pressure hypothesis argues that individual investors must be compensated for transaction costs and portfolio risks when they rely on public information to buy or sell stocks as this causes temporary stock price fluctuations (Kerl \& Walter, 2007). Previous studies have established evidence of price pressure hypothesis. Ben-Rephael, Kandel and Wohl (2011) examined Israel's stock mutual funds and discovered that fund flows and current market returns have a significant negative correlation which supports the price pressure hypothesis.

Ulku and Weber (2013) studied the relevance between Korean stock flows and market returns dividing stocks into three major investment groups, namely domestic individuals, domestic institutions, and foreign investors. The empirical results indicated that, of the three major investment groups, only the domestic stocks group supported the price pressure hypothesis.

Menkveld and Hendershott (2010) in their study of price pressures stated that stock market return is positively related to contemporaneous mutual fund flow but negatively related with lagged mutual fund flow. Menkveld and Hendershott defined price pressure in the stock market as the temporary deviations of stock prices from fundamental level due to a risk-averse intermediary supplying liquidity to asynchronously new investors with idiosyncratic hedging values. The theory provided another explanation for interactive relationship between fund flow and market return. When demand for stocks is not completely elastic and there is a large scale of net flow into stock mutual funds, the price pressure is then created by mutual fund flows. The stock prices are pushed up and are deviated from their fundamental value. The stock prices return to the level of fundamental value once the temporary price pressure has passed.

Sias, Starks, and Titman (2006) stated that the relation between changes in institutional ownership and measured over the same period is due to price effects associated with institutional trading. Sias et al. (2006) utilized a covariance decomposition method to estimate the relation between changes in quarterly ownership and daily returns, and concluded that institutional price pressure is the predominant explanation. There are three potential explanations for price changes associated with aggregate institutional trading: short-term liquidity effects, imperfect substitution and information revealed through institutional trading.

Elliot, Ness, Walker, and Warr (2006) suggested that index changes are associated with demand shocks that temporarily drive up or down the share prices as large order flows from index-tracking investors are fulfilled. Excess demand from indexing drains the existing market liquidity. Buying (selling) pressure causes the prices of stocks to deviate from its equilibrium level. The effect of excess demand is quickly mitigated as stock price rise (drop) to attract sellers (buyers), providing immediate liquidity. They further pointed out that when faced with large order flows, market makers incurred higher costs to maintain sufficient inventory. These costs are reflected in a security's bid-ask spread as market makers revise prices in accordance with perceived change in the riskiness of their inventory. The security prices returned to an equilibrium level when the demand shock was outweighed. Therefore, the price pressure hypothesis predicted a short-run increase or decrease in share prices of added or eliminated stocks.

\section{Methodology}

The study used causal research design which is more quantitative in nature as well as deliberate and configured design. Causal research design happen when variation in one incident, an independent variable, leads to, on average, a variation in another incident, the dependent variable (Delbert \& Neil, 2002).

The population of the study was 21 listed financial institutions in Kenya. Purposive sampling technique was used to select a sample size of 14 listed financial institutions whose monthly foreign data was available at Nairobi Securities Exchange for the period January 2008 to December 2014. The sample size of 14 listed financial institutions and the seven year period (January 2008 to December 2014) had been choosen on account of availability of monthly foreign data from NSE. The seven listed financial institutions that were left out were either listed later i.e. after 2008 or they were small in size hence inability to attract foreign investors resulting to lack of foreign data during the period of study.

Panel financial data for the seven year period that is January 2008 to December 2014 was used in the study to determine the effect of international portfolio equity outflows on security returns of listed financial institutions in Kenya. E-views software output was used to interpret regression coefficients. The study utilised secondary data which was collected from Kenya Bureaus of Statistics, Capital markets Authority, Central Bank of Kenya and Nairobi Securities Exchange.

Stock return as measured by changes in share prices is the increase in the price of a security over a period of time. 
Foreign portfolio equity sales are measured as changes in total monthly gross foreign equity sales. When foreign investors liquidate or sell their shares in the domestic market, there are outflows of foreign portfolios resulting to an anticipated decrease in stock returns. A negative relationship is expected between foreign portfolio equity sales and stock returns.

Unit root tests were conducted using the Levin, Lin and Chu unit root test method to ensure that the variables had no unit roots.

A panel data regression using the Ordinary Least Squares method was adopted in this study where data was pooled into a panel data set and estimated using panel data regression. Panel data is cross sectional time series data set that follows a given sample of individuals over time and hence resulting to multiple observations on each individual in the sample. Panel data is either balanced or unbalanced. A balanced panel data have some time periods for each cross - section observation while an unbalanced panel data has time dimension that is specific to each individual (Hsiao, 2003).

According to Wooldridge (2001) panel data has benefits. Panel data allows for a large number of data points, increasing the degrees of freedom and reducing collinearity among independent variables. Panel data also analyses a number of economic and financial issues that cannot be addressed using time series or cross- sectional data sets. Further, Panel data provides a way of resolving the magnitude of econometric problems that occur in empirical studies.

E- Views 7 data analysis software was used and the study hypotheses were measured using one panel data regression equation. The following regression model was used to test the hypotheses

$$
S R_{i t}=\alpha+\beta_{1} F P E S_{i t}+\beta_{2} F P E P_{i t}+\beta_{3} F P E T_{i t}+\beta_{4} E R R_{i t}+\beta_{5} T B I L i t+\beta_{6} I N F L_{i t}+\beta_{7} M C A P_{i t}+\mu_{i t}
$$

Where;

$S R_{i t}=$ Stock returns at time $t$,

$F P E S_{i t}=$ Foreign portfolio equity sales at time $t$,

$F P E P_{i t}=$ Foreign portfolio equity purchases at time $t$,

$F P E T_{i t}=$ Foreign portfolio equity turnover at time $t$,

$E R R_{i t}=$ Exchange rate risk at time $t$,

TBILit $=$ Treasury bill rate at time $t$,

$I N F L_{i t}=$ Inflation rate at time $t$,

$M C A P_{i t}=$ Market capitalization at time $t$,

$\alpha=$ The intercept,

$\beta_{i}=$ The parameter of explanatory variables of FPES, FPEP, FPET, ERR,TBIL, INFL and MCAP,

$\mu_{i}=$ The disturbance term.

\section{Discussion of Findings}

\subsection{The Effect of Foreign Portfolio Equity Sales on Stock Returns}

Table 1 presented descriptive statistics analysis results. All the variables were found to be stationary at intercept and level I (0) as per the unit root tests results. The Levin, Lin and Chu statistic for all the variables were significant at 1 percent level of significance therefore the null hypothesis that the variables have a unit root is rejected. The results are presented in table 2. Panel estimation output results on for the effect of international portfolio equity sales on stock returns of listed financial institutions in Kenya are as indicated by Table 3.

The results indicated that international portfolio equity sales had a negative coefficient of -0.002180 with Pvalue of 0.5188 which is insignificant. The results were insignificant implying that the negative effect is minimal and that international portfolio equity sales do not affect stock returns. This could mean that selling by foreign investors does not affect stock returns because investors selling decision might be affected mainly by some other factors such as behavioural differences, sentiments or reacting to false signals. The results are contrary to the studies done by Choei et al. (1999) and Dornbusch and Park (1995). Choei et al. (1999) found out that foreign investors liquidated their positions due to a drop in the return in the market before the economic turmoil in Korea. Dornbusch and Park (1995) asserted that because the international investors' transactions tend to be influenced by past market performances, foreign investors develop a tendency to acquire securities when the prices of these securities are rising and dispose when the prices are falling. 
Foreign portfolio equity sales do not have an effect on stock returns in Kenya's listed financial institutions; therefore the null hypothesis is accepted.

Table 1. Results for descriptive statistics

\begin{tabular}{lcccccccc}
\hline & SR & ERR & FPEP & FPES & FPET & INFL & MKTCAP & TBIL \\
\hline Mean & 1.093611 & 0.469930 & 10.76932 & 17.58135 & 0.247316 & 0.711501 & 7.310405 & 8.288214 \\
Median & 0.384064 & 0.475289 & 0.000000 & 0.000000 & 0.065579 & 0.529685 & 0.847458 & 8.185000 \\
Maximum & 263.6172 & 7.547826 & 3430.500 & 2634.752 & 4.658402 & 4.644044 & 1656.688 & 20.56000 \\
Minimum & -91.35867 & -7.903995 & -0.999922 & -0.999870 & 0.000000 & -0.856756 & -94.60131 & 1.630000 \\
Std. Dev. & 16.87420 & 2.512670 & 112.2023 & 145.8109 & 0.395549 & 0.867331 & 85.38968 & 3.743043 \\
Observations & 1176 & 1176 & 1176 & 1176 & 1176 & 1176 & 1176 & 1176 \\
\hline
\end{tabular}

Table 2. Results for stationarity test

\begin{tabular}{lcc}
\hline VARIABLES & Levin, Lin and Chu Statistic (Intercept) & Level of Integration \\
\hline SR & $-39.3470(0.0000)^{* * * *}$ & $\mathrm{I}(0)$ \\
ERR & $-22.2523(0.0000)^{* * *}$ & $\mathrm{I}(0)$ \\
FPEP & $-37.4225(0.0000)^{* * *}$ & $\mathrm{I}(0)$ \\
FPES & $-30.5492(0.0000)^{* * *}$ & $\mathrm{I}(0)$ \\
FPET & $-20.5634(0.0000)^{* * *}$ & $\mathrm{I}(0)$ \\
INFL & $-21.2828(0.0000)^{* * *}$ & $\mathrm{I}(0)$ \\
MKTCAP & $-43.3661(0.0000)^{* * *}$ & $\mathrm{I}(0)$ \\
TBIL & $-3.03863(0.0012)^{* * *}$ & $\mathrm{I}(0)$ \\
\hline
\end{tabular}

**Probabilities for Levin, Lin and Chu tests assume asymptotic normality.

*** Significant at $1 \%$ level of significance.

** Significant at $5 \%$ level of significance.

* Significant at $10 \%$ level of significance.

Table 3. Results from the panel estimation output

\begin{tabular}{lc}
\hline VARIABLE & RANDOM EFFECTS MODEL \\
\cline { 2 - 2 } ERR & Coefficient (P-Value) \\
FPEP & -0.758983 \\
& $(0.0002)^{* * *}$ \\
FPES & -0.000409 \\
& $(0.9254)$ \\
FPET & -0.002180 \\
& $(0.5188)$ \\
INFL & -1.029565 \\
& $(0.4191)$ \\
MKTCAP & -1.435119 \\
& $(0.0123)^{* *}$ \\
TBIL & 0.007181 \\
& $(0.2116)$ \\
C & -0.159235 \\
R- Squared & $(0.2492)$ \\
Prob (F- Statistic) & 4.036005 \\
Durbin- Watson Statistic & $(0.0024)$ \\
Nxt & 0.021380 \\
\hline
\end{tabular}

*** Significant at $1 \%$ level of significance.

** Significant at $5 \%$ level of significance.

* Significant at $10 \%$ level of significance. 


\subsection{Summary of the Findings}

The results indicated that foreign portfolio equity sales had a negative coefficient of -0.002180 with P- value of 0.5188 which is insignificant. The negative effect is minimal implying that the results were insignificant and that international portfolio equity outflows do not have an effect security returns. The null hypothesis stating that international portfolio equity outflows do not significantly affect security returns in Kenya's listed financial institutions fail to be rejected.

\section{Conclusion}

Foreign portfolio investments have been growing in developing countries, though the levels of foreign flows are still lower. The situation is the same in Kenya, particularly financial institutions. It is important for Capital markets authority/stock market regulators to think and prepare for the likely effects of foreign portfolio investments to the economy. Foreign capital is necessary for provision of capital and financing growth of firms such as commercial banks, insurance and investment companies in Kenya because they reduce the cost of capital and make it available to most firms.

The study found out that international portfolio equity outflows do not have an effect on security returns. The study concluded that foreign portfolio investment should be encouraged through proper policies so that the market is not affected much when there are foreign outflows.

\section{Recommendation}

Foreign investors liquidate their positions due to so many factors including but not limited the expectations and sentiments of foreign investors, terrorism, political instability, sovereign risk e.t.c. The study recommends that the government should put in place measures that discourage foreign outflows.

\section{References}

Ben-Rephael, A., Kandel, S., \& Wohl, A. (2011). The Price Pressure of Aggregate Mutual Fund Flows. Journal of Financial and Quantitative Analysis, 46, 585-603. https://doi.org/10.1017/S0022109010000797

Calvo, G. A., Izquierdo A., \& Mejia, L. F. (2008). Systematic sudden stops: The relevance of balance sheet effects and financial integration. NBER Working Paper, No. 14026.

Chen, J., \& Quang, T. (2012). International Financial Integration and Economic Growth: New Evidence on Threshold Effects. Paris School of Economics, 48 Boulevard Jourdan, 75014 Paris, France.

Choe, K., Kho, B., \& Stulz, R. (1999). Do Foreign Investors Destabilize Stock Markets? The Korean Experience in 1997. Journal of Financial Economics, 54, 227-264. https://doi.org/10.1016/S0304-405X(99)00037-9

Delbert, C. M., \& Neil, J. S. (2002). Handbook of Research Design and Social Measurement (6th ed.). Sage Publication, London.

Dornbusch, R., \& Park, Y. C. (1995). Financial Opening: Policy Lessons for Korea. Korea Institute of Finance, International Centre for Economic Growth.

Elliott, W. B., Ness, B. V., Walker, D., \& Warr, S. (2006). What drives the S\&P 500 inclusion effect? An analytical survey. Financial Management, 35, 31-48. https://doi.org/10.1111/j.1755-053X.2006.tb00158.x

Hsiao, C. (2003). Analysis of Panel Data (2nd ed.). Cambridge University Press. https://doi.org/10.1017/CBO9780511754203

International Monetary Fund. (2011). Recent experiences in managing capital inflows- cross cutting themes and possible framework. IMF policy paper.

Kerl, A. G., \& Walter, A. (2007). Market responses to buy recommendations issued by Personal Finance Magazines: Effects of information, price-pressure, and company characteristics. Review of Finance, 11(1), 117-141. https://doi.org/10.1093/rof/rfl004

Menkveld, J., \& Hendershott,T. (2010). Price Pressures. Western Finance Association papers.

Sharpe, W. F., Gordon J. A., \& Jeffery V. B. (2003). Investments (6th ed.). Prentice Hall of India Private Limited, New Delhi.

Sias, R. W., Starks, L. T., \& Titman, S. (2006). Changes in Institutional Ownership and Stock Returns: Assessment and Methodology. Journal of Business, 79(6), 2869-2910. https://doi.org/10.1086/508002

Ulku, N., \& Weber, E. (2013). Identifying the Interaction between Stock Market Returns and Trading Flows of Investor Types: Looking into the Day Using Daily Data. Journal of Banking and Finance, 37, 2733-2749. 
https://doi.org/10.1016/j.jbankfin.2013.03.021

Wooldridge, J. M. (2001). Econometric analysis of Cross section and Panel data. The MIT Press.

\section{Copyrights}

Copyright for this article is retained by the author(s), with first publication rights granted to the journal.

This is an open-access article distributed under the terms and conditions of the Creative Commons Attribution license (http://creativecommons.org/licenses/by/4.0/). 